Матеріали XIV Всеукраїнської науково-практичної конференції з міжнародною участю, присвяченої 60-річчю ТДМУ, “СУЧАСНІ ПЦДХОДИ ДО ВИЩОЇ МЕДИЧНОЇ ОСВІТИ В УКРАЇНІ”

Б. С. Зіменковський, М. Р. Гжегоцький, Є. С. Варивода, I. І. Солонинко, О. М. Чемерис, Н. Л. Чухрай

Львівський національний медичний університет імені Данила Галицького

\title{
ДОСВІД ВПРОВАДЖЕННЯ ІНДИВІДУАЛЬНОЇ САМОСТІЙНОЇ РОБОТИ ДЛЯ ІНОЗЕМНИХ СТУДЕНТІВ ЗА УМОВ ЄВРОПЕЙСЬКОЇ КРЕДИТНОЇ ТРАНСФЕРНО-НАКОПИЧУВАЛЬНОЇ СИСТЕМИ У ЛЬВІВСЬКОМУ НАЦІОНАЛЬНОМУ МЕДИЧНОМУ УНІВЕРСИТЕТІ ІМЕНІ ДАНИЛА ГАЛИЦЬКОГО
}

\author{
B. S. Zimenkovskyi, M. R. Hzhehotskyi, Ye. S. Varyvoda, I. I. Solonynko, \\ O. M. Chemerys, N. L. Chukhrai \\ Danylo Halytsky Lviv National Medical University
}

\section{EXPERIENCE OF INDIVIDUAL STUDENT'S WORK FOR FOREIGN STUDENTS IMPLEMENTATION IN THE CONTEXT OF EUROPEAN CREDIT TRANSFER-ACCUMULATION SYSTEM AT DANYLO HALYTSKY LVIV NATIONAL MEDICAL UNIVERSITY}

\footnotetext{
У статті висвітлено особливості реформування англомовного навчання іноземних студентів, відображено досвід застосування індивідуальної самостійної роботи студентів у контексті Європейської кредитної трансферно-накопичувальної системи у Львівському національному медичному університеті імені Данила Галицького.
}

Ключові слова: самостійна робота; студенти-іноземці.

The article deals with features of reforming teaching foreign students in English language; the experience of individual student's work in the context of European Credit Transfer-Accumulation System at Danylo Halytsky Lviv National Medical University is represented.

Key words: independent work; foreign students.

Вступ. Впровадження Європейської кредитної трансферно-накопичувальної системи (ЄКТС) організації навчального процесу в Україні є перспективним зближенням та інтеграцією вітчизняної системи освіти з європейською. Сформована під егідою Болонської декларації ЄКТС спрямована на впровадження загальноєвропейських норм в освіті й науці та поширення національних культурних і науково-технічних надбань серед європейських країн. Схема навчання за положеннями Болонської декларації $є$ не просто стратегією вибору, але й можливістю, що дозволяє нинішньому і майбутнім поколінням молодих людей, громадян України та чужоземних держав, отримати вищу освіту на рівні європейських і світових стандартів, які практично вже сформувалися і мають переваги перед нашою системою підготовки фахівців [1, 2].
Мета роботи - висвітлити досвід застосування індивідуальної самостійної роботи студентів у контексті Європейської кредитної трансферно-накопичувальної системи у Львівському національному медичному університеті імені Данила Галицького.

Основна частина. Відповідно до наказу Міністерства освіти і науки України від 26.01.2015 р. № 47 “Про особливості формування навчальних планів на 2015/2016 н.р.”, у ЛНМУ з 2015 р. розпочато реформування навчального процесу за кредитною трансферно-накопичувальною системою. На поточний момент цю систему навчання впроваджено на всіх курсах медичного факультету, стоматологічного та фармацевтичного факультетів. Створено нові навчальні плани у кредитах ЄКТС, структуровано програми з навчальних дисциплін, розроблено методичні рекомендації з відповідних

(с) Б. С. Зіменковський, М. Р. Гжегоцький, Є. С. Варивода та ін. 
дисциплін, вивчення клінічних дисциплін проводиться шляхом ротації циклів відповідних предметів з обов'язковим впровадженням принципів доказової медицини. Розроблено та затверджено положення про навчання іноземних студентів англійською мовою, яке грунтується на безумовному дотриманні всіх нормативних документів МОН і МОЗ України, Міністерства закордонних справ України, щодо правил запрошення, прийому, реєстрації та навчання іноземних громадян. Позитивним моментом слід вважати і те, що всі навчальні програми для англомовних студентів повністю приведені у відповідність до вимог і не відрізняються від базових програм, за якими навчаються українські студенти.

Клінічні дисципліни на кафедрах університету іноземні студенти починають опановувати з III-IV семестру залежно від факультету навчання. Вивчення предмета вимагає як базових знань, отриманих із середньої школи, фундаментальних знань, отриманих на початкових курсах навчання, логічного мислення, просторової уяви, так і мотивації студента до самостійного опрацювання теоретичного матеріалу з даної дисципліни. Одним із прикладів саморозвитку в навчанні студентів-іноземців може бути самостійна індивідуальна робота, яка належить до сучасних активних методів навчання, розвиває індивідуальні здібності та сприяє кращому засвоєнню необхідних знань. Це, безперечно, впливає на стимуляцію пізнавальної діяльності студентів. Окрім того, виконання самостійної роботи стимулює студента до опрацювання науково-методичної літератури, джерел інтернет-ресурсу, що $є$ важливим етапом на шляху оволодіння професійними знаннями та формування особистості лікаря [3].

3 огляду на вищевикладене, на кафедрах університету впроваджено певні види індивідуальної самостійної роботи студентів, результати якої представляють за допомогою інноваційних форм навчання, зокрема конкурсів на кращі студентські роботи. Така форма активізує розумову діяльність студентів, розвиває їх творчі здібності, формує вміння знаходити нестандартні шляхи вирішення

\section{Список літератури}

1. Ахапкіна Т. В. Спосіб організації навчального матеріалу з метою контролю / Т. В. Ахапкіна // Нові технології у навчальному процесі, теоретичної та клінічної медицини. Додаток до Одеського медичного журналу. - Одеса : Чорномор’я, 1999. - С. 22-24. поставлених завдань, розвиває комунікативні та психологічні можливості, вчить втілювати деонтологічні моменти в практику. Кращі студентські роботи знаходять своє практичне втілення на уроках здоров’я, круглих столах і конференціях [4].

Самостійна робота на кафедрах проводиться як у навчальний, так і в позанавчальний час із забезпеченням студентів відповідними навчальнометодичними матеріалами. Самостійний пошук інформації, моделюючи відповідний етап наукового дослідження, створює своєрідну творчу атмосферу. Це дозволяє зробити значно успішним та більш цікавим процес навчання.

На практичних заняттях студенти один на одному навчаються проводити клінічне обстеження хворого, антропометричні методи обстеження, отримувати результати клінічних обстежень із подальшим їх аналізом і застосуванням у практичній медицині.

Висновки. Поступовий розвиток англомовної форми навчання студентів-іноземних громадян згідно із положеннями Болонської системи - це не тільки великий обсяг надходжень до бюджету університету, але й грунтовний базис для серйозного вдосконалення і підвищення фахового рівня викладачів, можливість широкої та глибокої інтеграції наукових співпрацівників університету до європейської наукової спільноти. Навчання іноземних студентів вимагає від викладачів гнучкого індивідуального підходу, врахування труднощів, які виникають у них під час спілкування, особливо на перших курсах. Стимулювання студентів-іноземців до самостійного пошуку та опрацювання науковометодичної літератури, джерел інтернет-ресурсу $є$ необхідним для формування особистості сучасного лікаря. Зворотний зв'язок з випускниками, наявність великої кількості іноземних студентів-випускників, охочих продовжувати навчання в Львівському національному медичному університеті імені Данила Галицького за різними спеціальностями у клінічній ординатурі, показують позитивний досвід роботи кафедр, що також підтверджується їх успішним працевлаштуванням у державних та приватних медичних закладах своїх країн.

2. Ковальчук Л. Я. Основні тенденції розвитку світової вищої школи. Впровадження сучасних технологій у навчальний процес Тернопільської медичної академії ім. І. Я. Горбачевського: досягнення і перспективи / Л. Я. Ковальчук // Медична освіта. - 2000. - № 2. - С. 5-11. 
3. Форми і методи активізації навчального процесу при викладанні стоматології дитячого віку іноземним студентам / П. І. Ткаченко, Л. Ф. Каськова, О. Ю. Андріянова [та ін.] // Матеріали Х Всеукр. навч.-наук. конф. 3 міжнар. участю. - Тернопіль, 2009. - С. 202-204.

4. Підготовка іноземних студентів за спеціальністю “Стоматологія” у контексті євроінтеграції української

\section{References}

1. Akhapkina, T.V. (1999). Sposib orhanizatsii navchalnoho materialu $\mathrm{z}$ metoiu kontroliu [Arrangement of educational material with a view to monitoring]. Novi tekhnolohii $u$ navchalnomu protsesi, teoretychnoi ta klinichnoi medytsyny. Dodatok do Odeskoho medychnoho zhurnalu - New technologies in educational process of theoretical and clinical medicine. Appendix to Odesa medical journal. Odesa: Chornomoria [in Ukrainian].

2. Kovalchuk, L.Ya. (2000). Osnovni tendentsii rozvytku svitovoi vyshchoi shkoly. Vprovadzhennia suchasnykh tekhnolohii u navchalnyi protses Ternopilskoi medychnoi akademii im. I. Ya. Horbachevskoho: dosiahnennia i perspektyvy [Main trend of world higher education development. Implementation of modern technologies into educational process of Ternopil Medical Academy by I. Ya Horbachevskyi: results and prospects]. Medychna osvita-Medical education, 2, 5-11 [in Ukrainian].

3. Tkachenko, P.I., Kaskova, L.F., \& Andriianova, O.Yu. (2009). Formy i metody aktyvizatsii navchalnoho protsesu pry vykladanni stomatolohii dytiachoho viku inozemnym studentam [Forms and methods of education process activization during teaching Pediatric Dentistry for foreign stu- вищої освіти / Б. С. Зіменковський, М. Р. Гжегоцький, Є. С. Варивода [та ін.] // Реалізація Закону України “Про вищу освіту” у вищій медичній та фармацевтичній освіті України : матеріали Всеукр. навч.-наук. конф. з міжнар. участю, присвяченої пам'яті ректора чл.-кор. НАМН України, проф. Л. Я. Ковальчука (Тернопіль, 21-22 трав. 2015 р.). - Тернопіль, 2015. - С. 50-55.

dents]. Mat. X Vseukrainskoi navchalno-naukovoi konferentsii z mizhnarodnoiu uchastiu - Materials of all-Ukrainian educational and scientific conference with international participation. Ternopil [in Ukrainian].

4. Zimenkovskyi, B.S., Hzhehotskyi, M.R., Varyvoda, Ye.S., Chukhrai, N.L., \& Solonynko, I.I. (2015). Pidhotovka inozemnykh studentiv za spetsialnistiu «Stomatolohiia» u konteksti yevrointehratsii ukrainskoi vyshchoi osvity [Foreign students training in Dentistry in the context of higher education in Ukraine]. Materialy Vseukrainskoi navchalno-naukovoi konferentsii z mizhnarodnoiu uchastiu, prysviachenoi pamiati rektora, chlena-korespondenta NAMN Ukrainy Leonida Yakymovycha Kovalchuka «Realizatsiia zakonu Ukrainy «Pro vyshchu osvitu» u vyshchii medychnii ta farmatsevtychnii osviti Ukrainy», Ternopil, 21-22 travnia 2015 r. - Materials of all-Ukrainian educational and scientific conference with international participation, dedicated to the memory of rector, associate member of NAMS of Ukraine Leonid Yakymovych Kovalchuk «The Higher Education Act of Ukraine» in higher medical and pharmaceutical education of Ukraine implementation», Ternopil, May 21-22, 2015. Ternopil [in Ukrainian].

Електронна адреса для листування: orestchemerys@gmail.com. 